University of Nebraska - Lincoln

DigitalCommons@University of Nebraska - Lincoln

$2-2012$

\title{
Complex terrain leads to bidirectional responses of soil respiration to inter-annual water availability
}

\author{
Diego Andrés Riveros-Iregui \\ University of Nebraska - Lincoln, driveros2@unl.edu \\ Brian L. McGlynn \\ Montana State University - Bozeman, bmcglynn@montana.edu \\ Ryan E. Emanuel \\ North Carolina State University at Raleigh, ryan_emanuel@ncsu.edu \\ Howard E. Epstein \\ University of Virginia - Main Campus, hee2b@virginia.edu
}

Follow this and additional works at: https://digitalcommons.unl.edu/natrespapers

Part of the Natural Resources and Conservation Commons

Riveros-Iregui, Diego Andrés; McGlynn, Brian L.; Emanuel, Ryan E.; and Epstein, Howard E., "Complex terrain leads to bidirectional responses of soil respiration to inter-annual water availability" (2012). Papers in Natural Resources. 315.

https://digitalcommons.unl.edu/natrespapers/315

This Article is brought to you for free and open access by the Natural Resources, School of at DigitalCommons@University of Nebraska - Lincoln. It has been accepted for inclusion in Papers in Natural Resources by an authorized administrator of DigitalCommons@University of Nebraska - Lincoln. 


\title{
Complex terrain leads to bidirectional responses of soil respiration to inter-annual water availability
}

\author{
Diego A. Riveros-Iregui, ${ }^{1}$ Brian L. McGlynn, ${ }^{2}$ Ryan E. Emanuel, ${ }^{3}$ and Howard E. Epstein ${ }^{4}$ \\ 1. School of Natural Resources, University of Nebraska, 3310 Holdrege Street, Lincoln, NE 68583-0995 \\ 2. Department of Land Resources and Environmental Sciences, Montana State University, 334 Leon Johnson Hall, Bozeman, MT 59717 \\ 3. Department of Forestry and Environmental Resources, North Carolina State University, 3120 Jordan Hall, Raleigh, NC 27695 \\ 4. Department of Environmental Sciences, University of Virginia, Charlottesville, VA 22904
}

Corresponding author - Diego Riveros-Iregui, tel 402 472-8198, fax 402 472-2946, email driveros2@unl.edu

\begin{abstract}
Research on the terrestrial $\mathrm{C}$ balance focuses largely on measuring and predicting responses of ecosystem-scale production and respiration to changing temperatures and hydrologic regimes. However, landscape morphology can modify the availability of resources from year to year by imposing physical gradients that redistribute soil water and other biophysical variables within ecosystems. This article demonstrates that the well-established biophysical relationship between soil respiration and soil moisture interacts with topographic structure to create bidirectional (i.e., opposite) responses of soil respiration to inter-annual soil water availability within the landscape. Based on soil respiration measurements taken at a subalpine forest in central Montana, we found that locations with high drainage areas (i.e., lowlands and wet areas of the forest) had higher cumulative soil respiration in dry years, whereas locations with low drainage areas (i.e., uplands and dry areas of the forest) had higher cumulative soil respiration in wet years. Our results indicate that for $80.9 \%$ of the forest soil respiration is likely to increase during wet years, whereas for $19.1 \%$ of the forest soil respiration is likely to decrease under the same hydrologic conditions. This emergent, bidirectional behavior is generated from the interaction of three relatively simple elements (parabolic soil biophysics, the relative distribution of landscape positions, and inter-annual climate variability), indicating that terrain complexity is an important mediator of the landscape-scale soil C response to climate. These results highlight that evaluating and predicting ecosystem-scale soil $\mathrm{C}$ response to climate fluctuation requires detailed characterization of biophysical-topographic interactions in addition to biophysical-climate interactions.
\end{abstract}

Keywords: bi-directional response, climate change, hydrology, inter-annual variability, mountainous terrain

\section{Introduction}

Understanding ecosystem responses to inter-annual climate variability is a central challenge facing the global change community (IPCC, 2007, Yuan et al., 2009). Research on the terrestrial $\mathrm{C}$ balance focuses largely on measuring and predicting responses of ecosystem-scale production and respiration to changing temperatures and hydrologic regimes (Law et al., 2002; Luyssaert et al., 2007; Bond-Lamberty \& Thomson, 2010). However, landscape morphology can modify the availability of resources from year to year by imposing physical gradients that redistribute soil water and other biophysical variables within ecosystems (Jencso et al., 2009). Mountainous terrain imposes spatial variability on the horizontal redistribution of soil water, snow, insolation, and other biophysical resources. Current studies investigate how the variability of these resources will be affected by warming climate scenarios, and how such changes will affect spatiotemporal trends of water-mediated processes. Previous and current efforts have focused on temporal comparisons of carbon fluxes across sites, throughout successional stages, or along environmental gradients of precipitation and temperature (e.g., Piao et al., 2007; Stoy et al., 2008; Anderson-Teixeira et al., 2011). However, the potential for bidirectional responses of carbon fluxes to inter-annual climate variability, especially within single ecosystems, remains unknown.

The western United States is likely to experience earlier snow melt in the future (Barnett et al., 2005; Mote et al., 2005). As a result, spring runoff will increase and low areas of mountainous landscapes (e.g., riparian areas) will become wetter earlier in the growing season. Additionally, high and steep areas (i.e., typically forested slopes and ridges) will dry out faster. Carbon cycle studies in com- 
plex terrain assume or are typically conditioned on monotonic (i.e., unidirectional) responses of soil respiration to water variability within the ecosystem. For example, Monson et al. (2006) developed first-order exponential coefficients to describe the temperature sensitivity of soil respiration beneath snowpacks, demonstrating that shallower snowpacks could potentially reduce soil $\mathrm{CO}_{2}$ loss from mountain forest ecosystems. However, their study was conducted in a well-drained upland site (Niwot Ridge Ameriflux Site, CO, USA), and such monotonically increasing relationships are conditioned to low soil water content. It is likely that those relationships will show limitations to quantifying large-scale soil respiration across great ranges in soil moisture (e.g., at persistently saturated soils) or in more poorly drained areas of the landscape. Schuur et al. (2009) extrapolated upland, permafrost soil $\mathrm{CO}_{2}$ dynamics to the global permafrost $C$ pool to determine potential $\mathrm{CO}_{2}$ emissions, assuming that upland dynamics are similar elsewhere. Yet, these authors recognized that "[i]f anaerobic conditions are more typical in lowland landscapes, then [the] estimate will have overestimated total $\mathrm{C}$ emissions to the atmosphere, but will still accurately account for the climate impact of permafrost thaw." How biological activity, including autotrophic and heterotrophic respiration, will respond to projected hydrologic changes in complex terrain, and how these changes will in turn affect net ecosystem productivity (NEP) in mountainous forests (e.g., Desai et al., in press) remain to be addressed.

This article investigates the effects of inter-annual water availability and landscape morphology on driving the spatial variability of belowground processes, namely flux of soil $\mathrm{CO}_{2}$ to the atmosphere. We address this by measuring soil respiration (also referred to as soil $\mathrm{CO}_{2}$ efflux) in a subalpine forest of central Montana across two hydrologically different growing seasons (i.e., a "wet" year and a "dry" year). Previous studies demonstrated the potential for differential responses of soil respiration across singular landscape elements, using soil respiration plots located within $50 \mathrm{~m}$ of the stream channel (Pacific et al., 2009). Here, we consider 62 soil respiration plots distributed across the entire watershed $\left(3.9 \mathrm{~km}^{2}\right)$ at distances up to $\sim 1000 \mathrm{~m}$ from the stream. More importantly, we examine landscape position as a continuous variable using the calculated drainage area for each pixel of the landscape. This is a considerable advancement from previous studies because for the first time it allows (1) evaluation and treatment of the landscape as a continuously distributed variable; and (2) assessment of the spatial manifestation of the parabolic relationship between soil respiration and soil moisture, as mediated by landscape structure. We hypothesize that complex terrain facilitates a spatiotemporal organization of soil respiration at the landscape scale via the horizontal redistribution of soil water, and spatially correlated variables such as vegetation and physical and chemical properties of the soil. Information gained through this research will enhance our understanding of the effects of varying hydrologic regimes on landscape-scale soil respiration and improve our capacity to assess the effects of different climate scenarios on the net ecosystem carbon balance of mountainous forests.

\section{Methods}

\section{Site description}

This study was conducted in the Upper Stringer Creek Watershed ( $\left.46^{\circ} 55 \mathrm{~N} ; 110^{\circ} 54 \mathrm{~W}\right)$, a sub-watershed of the Tenderfoot Creek Experimental Forest (TCEF). TCEF is a subalpine forest located in the Little Belt Mountains of central Montana and operated by the US Forest Service. Tenderfoot Creek drains into the Smith River, which is a tributary of the Missouri River. The elevation within the Upper Stringer Creek Watershed ranges from 2090 to $2421 \mathrm{~m}$ and the watershed has an area of $3.9 \mathrm{~km}^{2}$. A snow survey telemetry station (Stringer SNOTEL, National Resources Conservation Service, http://www.wcc.nrcs.usda.gov/snotel/) was located $<1 \mathrm{~km}$ south of the Upper Stringer Creek Watershed. This station provided real-time data for the 2005 and 2006 water years, including snow depth, snow water equivalent (SWE), and total precipitation. The two predominant ecosystems at this site were riparian meadows (near the Stringer Creek channel) and upland forests. Vegetation cover at riparian meadows consisted primarily of Calamagrostis canadensis (bluejoint reedgrass), whereas upland forests were vegetated mostly by Pinus contorta (lodgepole pine) and to a lesser extent Abies lasiocarpa (Subalpine fir) and Picea Engelmannii (Engelmann Spruce). Vaccinium scoparium (Whortleberry) was the predominant understory species.

\section{Terrain variability}

Using a $3 \mathrm{~m}$ digital elevation model (DEM) derived from Airborne Laser Swath Mapping (courtesy of the National Center for Airborne Laser Mapping at the University of California, Berkeley), we calculated the drainage area $\left(\mathrm{m}^{2}\right)$ for each pixel of the watershed based on the triangular multiple flow direction algorithm (Seibert \& McGlynn, 2007). The drainage area is the area draining to a particular location on the landscape and serves as a quantification of relative soil wetness potential (Beven et al., 1979; McGlynn \& Seibert, 2003). Sponseller \& Fisher (2008) and RiverosIregui \& McGlynn (2009) have previously demonstrated that landscape position and drainage area are strong predictors of the spatial variability of soil respiration at seasonal time scales.

\section{Soil respiration and soil water content measurements}

Soil respiration was measured at 62 soil respiration plots located across the $3.9 \mathrm{~km}^{2}$, Upper Stringer Watershed. Each plot consisted of a $0.5 \mathrm{~m}^{2}$ plot, roped off to minimize disturbance. Soil respiration was measured using a soil respiration chamber model SRC-1 (footprint of $314.2 \mathrm{~cm}^{2}$, accuracy within $1 \%$ of calibrated range $\left(0-9.99 \mathrm{~g} \mathrm{CO}_{2} \mathrm{~m}^{-2} \mathrm{~h}^{-1}\right)$, 
PP Systems, MA, USA) and an infrared gas analyzer [EGM4 , accuracy within $1 \%$ of calibrated of calibrated range (0-2000 ppm)]. Three soil chamber measurements were collected at each of the 62 sites every 2-7 days, over a sampling period between June 9 and August 30 in each year (2005 and 2006). Vegetation was clipped once a week after measurements were collected and roots were not disturbed. Prior to each measurement, the chamber was flushed with ambient air for $15 \mathrm{~s}$ and placed onto the soil, ensuring a good seal between the chamber and the soil surface. Soil $\mathrm{CO}_{2}$ efflux was calculated by measuring the rate of increase in $\mathrm{CO}_{2}$ concentration within the chamber and fitting a quadratic equation to the relationship between the increasing $\mathrm{CO}_{2}$ concentration and elapsed time. To minimize introduction of biases during sampling, no chamber measurements were taken before 1000 LT or after 1600 LT. Additional details regarding sampling protocol have been described in previous studies (Pacific et al., 2008; RiverosIregui et al., 2008). Growing season (cumulative) flux was calculated by linearly interpolating between measurements. Riveros-Iregui et al. (2008) analyzed potential artifacts introduced by this approach and demonstrated that sampling frequency, linear interpolation between measurements, and time of day do not bias estimates of soil respiration when analyzed cumulatively (seasonally).

Volumetric soil water content was measured three times at each plot every time that soil respiration was measured. Measurements integrated the top $20 \mathrm{~cm}$ of the soil and were made using a portable meter (Hydrosense, Campbell Scientific, Logan, UT, USA). Measurements were corroborated with traditional time domain reflectometry (TDR) in the lab and in the field to ensure data reliability $\left(r^{2}=0.986\right)$.

We calculated the difference of soil respiration between seasonal soil respiration measured in 2005 and 2006 and correlated this difference with drainage area. Drainage area values were considered outliers and excluded from all analyses if they fell outside a $90 \%$ confidence interval of a Studentized $t$-distribution of the residuals (Chatterjee \& Hadi, 1986). Additionally, we used the jackknife method to assess the statistical significance of this correlation by repeatedly choosing a subset of $n-1$ samples from the original dataset ( $n=58$; excluding outliers). As with the bootstrap method, the jackknife method provides better information on the characteristics of the population than the statistical parameters from the full dataset (Trauth, 2007). Results from our analysis, including uncertainty bounds, are reported as the mean and 1 SD of 58 linear regressions. All statistical analyses were performed using Matlab 7.10.0 (The MathWorks, Inc., Natick, MA, USA).

\section{Results}

\section{Hydrometeorology}

The hydrometeorology of the 2005 and 2006 water years is summarized in Fig. 1 (note that a water year is marked by the 12 month period from October through September, designated by the calendar year in which it ends). Despite a marked difference in SWE maxima between 2005 and 2006 (277 mm vs. $350 \mathrm{~mm}$, respectively), SWE increased earlier during 2006 relative to 2005. This resulted in a peak of SWE that occurred 16 days earlier during 2006 than 2005. Concomitantly, total precipitation (relative to May 1) was $~ 30 \%$ higher in 2005 than 2006 (375 mm vs. 282 mm; Fig. 1), indicating higher rainfall during the 2005 growing season (especially marked after June 1). Mean values of volumetric soil water content ranged from 0.10 to 0.75 during the 2005 and 2006 (Fig. 2). Comparing the 2 years, it is especially evident that those locations with persistently high soil moisture $(>25 \%)$ are relatively much wetter during 2005 than those locations with lower soil moisture $(<25 \%)$. In fact, the relative increase in soil moisture between 2005 and 2006 (Fig. 2) was significantly different between dry locations and wet locations (Wilcoxon rank sum test, 95\% significance level). Taken together, these results demonstrate that (1) the 2005 growing season was relatively wetter than the 2006 growing season, owing to differences in snow melt timing and the total precipitation inputs; and (2) inter-annual changes in soil moisture occur differently across the landscape with lowland areas having relatively higher soil moisture in wet years than upland areas.

\section{Soil respiration rates across two growing seasons}

Seasonal rates of soil respiration ranged from $\sim 400$ to $\sim 2500 \mathrm{~g} \mathrm{CO}_{2} \mathrm{~m}^{-2} 83 \mathrm{day}^{-1}$ during both years (Fig. 3). Looking at the variability of these fluxes across 2005 and 2006, it is noted that the difference is not significant between years (mean soil respiration rates are 996.0 and $1000.7 \mathrm{~g}$ $\mathrm{CO}_{2} \mathrm{~m}^{-2} 83 \mathrm{day}^{-1}$, respectively; $P=0.93$, ANova). In fact, at first it appears that the scatter of all data points falls well along the 1 : 1 line (Fig. 3). However, a significant correlation emerged between the difference of soil respiration between the 2 years and drainage area $\left(r^{2}=0.25 ; P<0.0001\right.$ based on least-squares regression; Fig. 4), indicating that locations with high drainage areas have higher cumulative soil respiration in dry years, whereas locations with low drainage areas have higher cumulative soil respiration in wet years. Based on this correlation (Fig. 4), we derived the drainage area for which soil respiration would be the same in both years. This area, or the "hinge point," was $1287 \mathrm{~m}^{2} \pm 25 \mathrm{~m}^{2}$ (1 mean and 1 SD of 58 least-squares regressions) between 2005 and 2006. We used this hinge point to visualize the forest into two behavioral states (Fig. 5). Our results indicate that $80.9 \%$ of the forest is below the hinge point and for those areas soil respiration is likely to increase during wet years. On the other hand, $19.1 \%$ of the forest is above the hinge point and for those areas soil respiration is likely to decrease under the same conditions. 

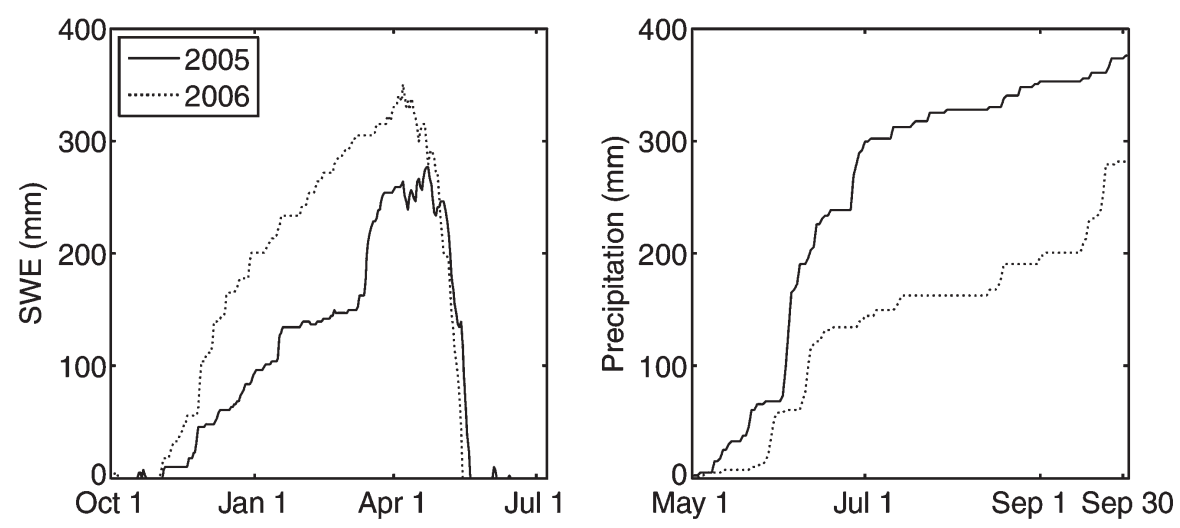

Figure 1. Snow water equivalent (SWE; left panel) and total precipitation (right panel) measured at the Stringer SNOTEL during the 2005 and 2006 water years (a water year is a 12 month period from October through September, designated by the calendar year in which it ends). Despite having greater SWE, snow melt during 2006 peaked 16 days earlier, which resulted in a much drier growing season. Simultaneously, cumulative precipitation relative to May 1 was relatively higher during 2005.

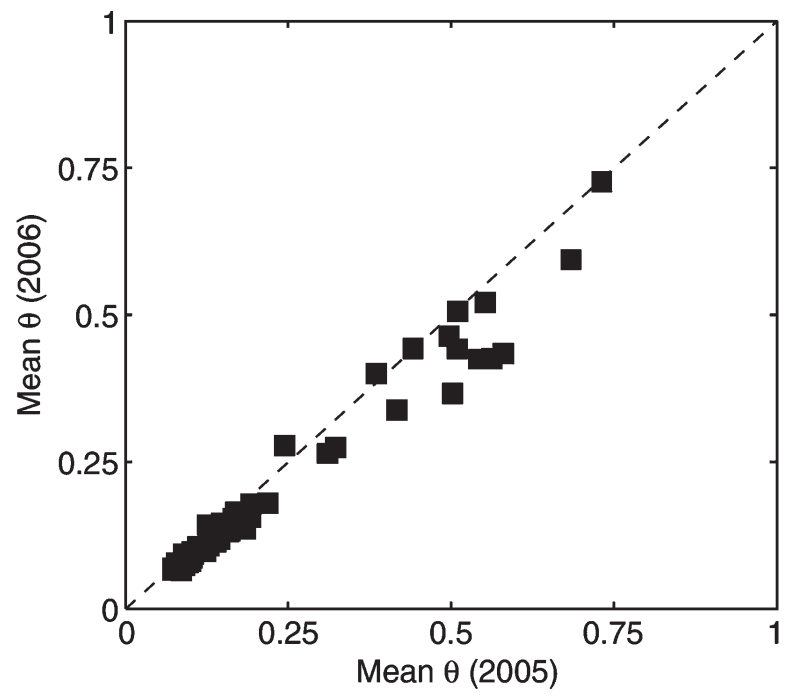

Figure 2. Growing season means of soil water content $(\theta)$ across 62 locations of a subalpine forest during 2005 and 2006. Soil water content was relatively higher during 2005 than 2006, particularly in wetter areas of the landscape (lowlands).

\section{Discussion}

Understanding the responses of ecosystem-scale soil respiration and $C$ exchange to changing environmental conditions has been the focus of many studies in complex terrain, from both modeling (Wilson \& Baldocchi, 2001; Montagnani et al., 2009) and empirical (Monson et al., 2006; Schuur et al., 2009) perspectives. Their studies quantified and predicted the temporal variability of soil respiration for many ecosystems and biomes. Our field observations demonstrate that overestimating soil respiration is possible in low areas of mountainous landscapes or in upland locations of high drainage area. More importantly, our findings show that bidirectional behavior emerges in the response

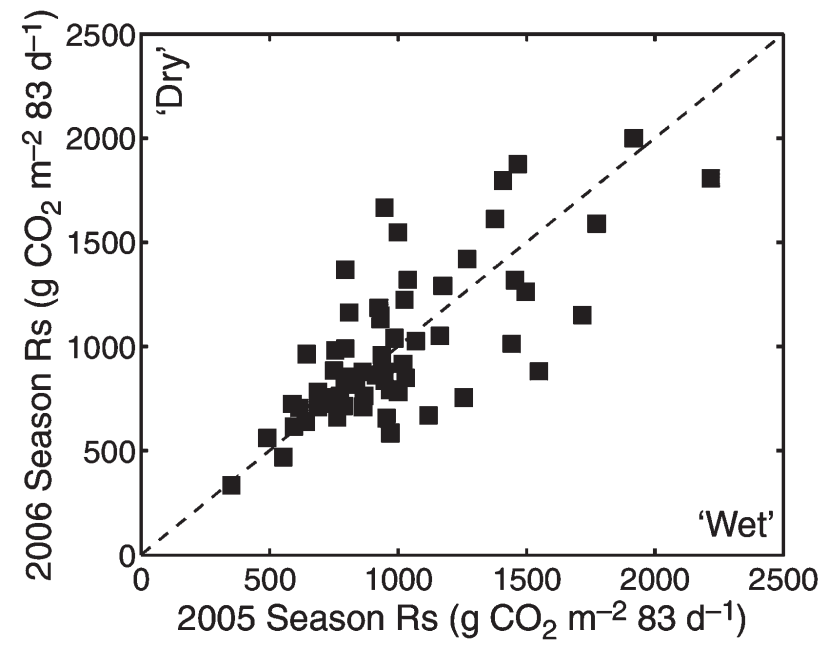

Figure 3. Growing season rates (83 day cumulative) of soil respiration $\left(R_{S}\right)$ across the 62 locations, and during the 2005 and 2006 growing seasons ("wet" and "dry" growing seasons, respectively). Cumulative $R_{S}$ rates were not significantly different between years (mean $R_{S}$ rates are 996.0 and $1000.7 \mathrm{~g} \mathrm{CO}_{2} \mathrm{~m}^{-2} 83$ day $^{-1}$, respectively; $P=0.93$, ANOvA).

of soil respiration to inter-annual water availability in complex terrain.

Complex terrain fosters bidirectional responses to changing hydrologic regimes because of topographydriven, horizontal redistribution of soil water and likely associated mobilized solutes. This means that year-to-year changes in snow or rainfall will result in different soil water content across the landscape with some areas increasing or decreasing more than others (Fig. 2). Here, the horizontal redistribution of water was quantified by the "drainage area" metric, and its effects on soil respiration were quantified via a threshold for bidirectional response in space. For this mountainous ecosystem, we calculated a hinge point of $1287 \mathrm{~m}^{2} \pm 25 \mathrm{~m}^{2}$ between 2005 and 2006 with soil respira- 


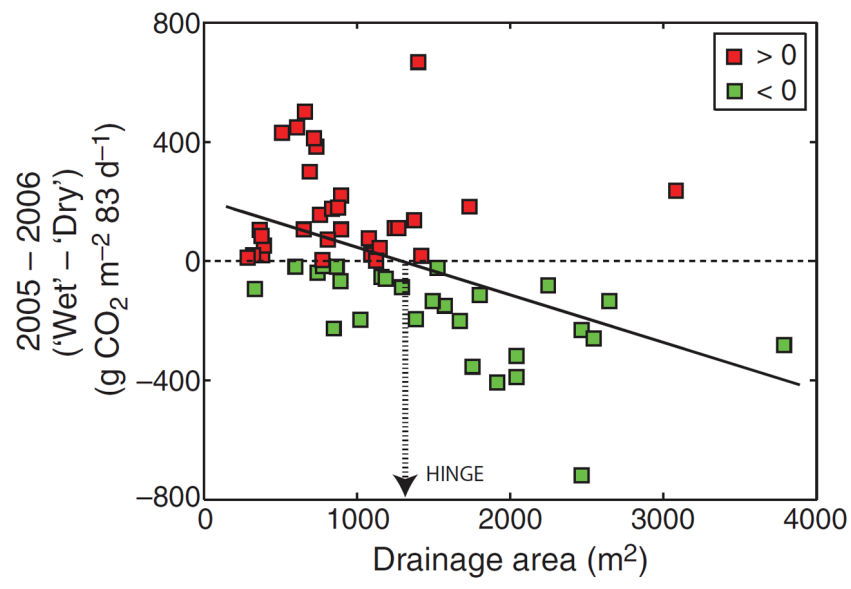

Figure 4. The relationship between the inter-annual difference of soil respiration (2005-2006) and drainage area (Seibert \& McGlynn, 2007)) across the Upper Stringer Creek Watershed. Locations with a positive difference $\left(R_{S}\right.$ in $2005>R_{S}$ in 2006) are denoted in red, whereas locations with a negative difference $\left(R_{S}\right.$ in $2005<R_{S}$ in 2006) are denoted in green. These results demonstrate that locations with high drainage areas have higher cumulative soil respiration in dry years and locations with low drainage areas have higher cumulative soil respiration in wet years.

tion rates differing by as much as $\pm 700 \mathrm{~g} \mathrm{CO}_{2} \mathrm{~m}^{-2} 83$ day $^{-1}$ between years (Fig. 4). Below the hinge point (for landscape locations with drainage area smaller than the hinge point), it is likely that the soil is well aerated and root and microbial activities benefit from adequate oxygen diffusion and mobilization of other substrates into the soil column. Under these conditions, soil respiration increases with additional water inputs (Liu et al., 2002; Huxman et al., 2004; Xu et al., 2004) and wetter years promote higher biological activity and higher rates of soil respiration. However, above the hinge point (for landscape locations with drainage area greater than the hinge point), it is likely that soil water content is high and additional inputs of soil water further reduce aeration and diffusivity of oxygen and soil $\left(\mathrm{CO}_{2}\right)$. Under such conditions, soil respiration decreases with increasing water availability (Greaves \& Carter, 1920; Linn \& Doran, 1984; Skopp et al., 1990; Pacific et al., 2011) and wetter years can result in lower rates of soil $\mathrm{CO}_{2}$ flux from the soil surface. While at the landscape scale, this relationship can be reduced to 'binary' behavior (wet vs. dry), the biophysics are not simply binary but rather a continuous function distributed across the landscape (Figs 4 and 5). It is important to highlight that the transition zone contains a new, emergent variable: the threshold area above which these differences in soil moisture may limit soil aeration (i.e., the hinge point). The drainage area metric subsumes the history of water redistribution across the landscape and the mobilization of associated solutes and biophysical, explaining why at the landscape scale instantaneous water content alone is not a sufficient predictor of the fluxes (Riveros-Iregui \& McGlynn, 2009).
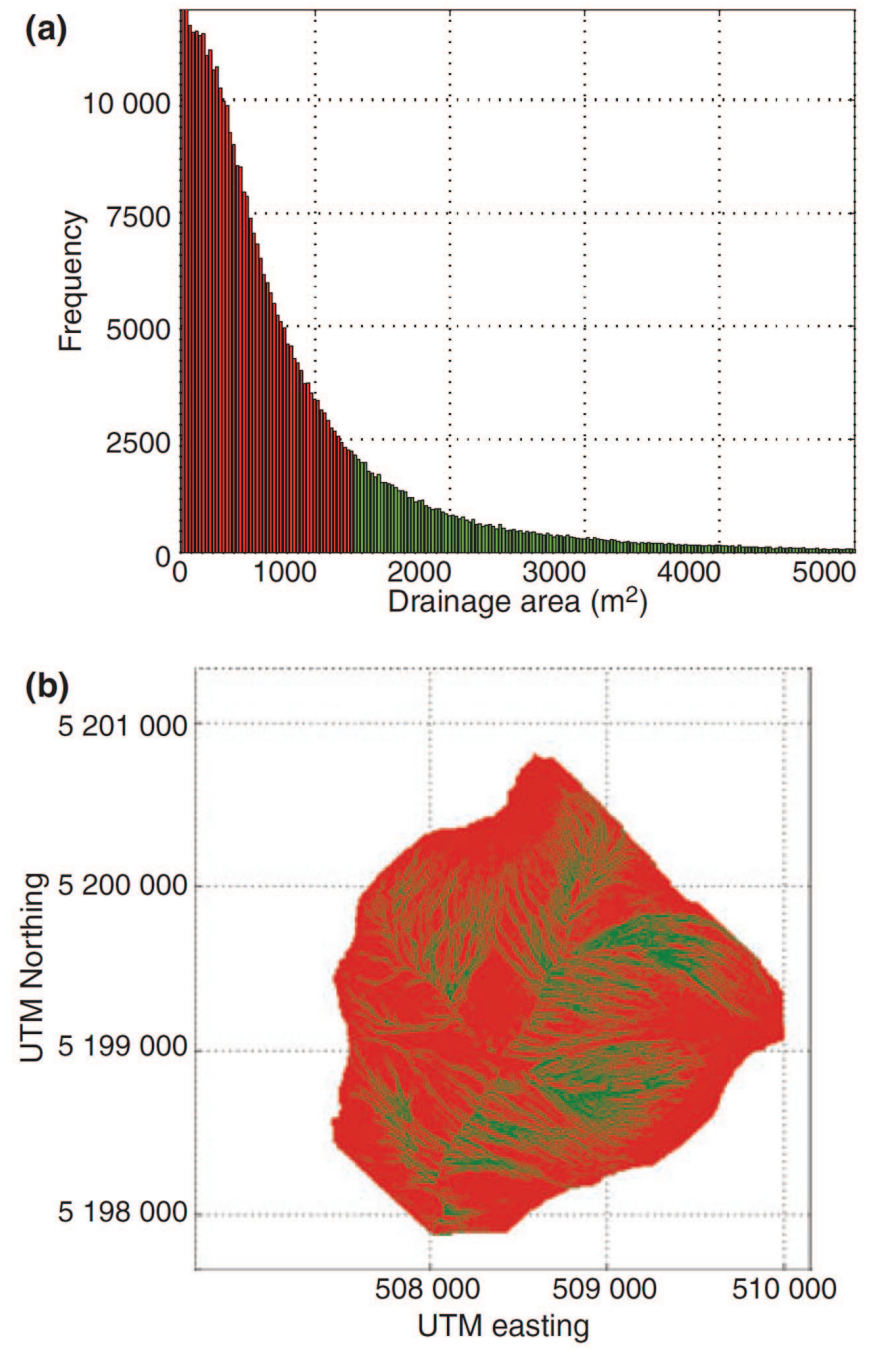

Figure 5. (a) Using the hinge point calculated in Fig. 4, we divided the frequency distribution of $3 \mathrm{~m}$ drainage areas across the Upper Stringer Watershed into two groups. Grid cells with drainage area smaller than the hinge point are denoted in red, whereas grid cells with drainage area greater than the hinge point are denoted in green. (b) Same as 5a, but on a map view.

Variability in inter-annual precipitation or snow melt timing can impose further spatial variability in soil water and directly affect soil $\mathrm{C}$ and nutrient transformation across large areas. It is well recognized that many field and modeling studies use a parabolic relationship to describe the response of soil respiration to soil water content (e.g., Skopp et al., 1990; Mielnick \& Dugas, 2000; Liu et al., 2002; Xu et al., 2004); however, implementing the parabolic relationship assuming that landscape dynamics are similar everywhere does not necessarily capture the emergent, bidirectional behavior observed from year to year. We suggest that the spatial manifestation of the parabolic relationship is strongly mediated by landscape structure and propose that bidirectional responses are the result of three relatively simple elements combined: para- 
bolic soil biophysics, the relative distribution of landscape positions, and inter-annual climate variability. We suggest that, at least for mountainous terrain, modeling bidirectional behavior will require the implementation and parameterization of these elements: (1) parabolic soil biophysics, as represented by the parabolic relationship between soil moisture and soil respiration; (2) the relative distribution of landscape positions, given that drainage area and soil moisture vary with landscape position; (3) and inter-annual climate variability, given that as landscape position changes so does the response of local soil moisture to different precipitation inputs - this element represents a long-standing challenge in the hydrologic sciences (e.g., Sivapalan \& Wood, 1986; Rodriguez-Iturbe et al., 1991; Western et al., 2002). Thus, it is expected that the absolute value of the hinge point vary from year to year or from ecosystem to ecosystem, depending on the combination of these three elements. It is also expected that the effects of elements (2) and (3) diminish as landscape complexity diminishes, ending at the case of the idealized flat landscape with homogeneously distributed soil moisture and biophysical resources (in this landscape only the parabolic relationship between soil moisture and soil respiration suffices because the entire landscape behaves essentially in the same way).

The findings presented here clearly demonstrate that bidirectional responses of soil respiration to changing hydrologic regimes can be very important and significant, even across short distances of complex terrain (this watershed is $3.9 \mathrm{~km}^{2}$ ). Bidirectional responses can be particularly prominent in other low and wet landscape areas such as intermountain wetlands or in areas where climate change may promote an early increase in soil moisture due to early snow melt (Barnett et al., 2005). Changes in soil water in low areas will simultaneously facilitate generation and flux of other important greenhouse gases (i.e., $\mathrm{CH}_{4}, \mathrm{~N}_{2} \mathrm{O}$ ) (Lohse et al., 2009) and stream carbon export (Kindler et al., 2011) that can further challenge biogeochemical quantifications at landscape and regional scales. In fact, increases in landscape-scale $\mathrm{CH}_{4}$ emissions from lowland, permafrost areas have been attributed to changes in the microtopography, hydrologic conditions, in addition to changes in vegetation cover (Christensen et al., 2004; Walter et al., 2006). As in these studies, our study focused on the effects imposed by topographic variability; however, similar bidirectional response could also be observed with regards to productivity and vegetation responses to climate, or in response to the spatial variability of the vegetation itself, soil nutrient status, and other soil forming factors (Jenny, 1941). In fact, most ecosystems are characterized by reduced vegetation productivity during dry years; however, for systems where productivity is normally limited by too much water (e.g., forested wetlands) dry years can actually facilitate increased production (see long term spatio-temporal analysis by Conner et al., 2011). Future studies should focus on how landscape characteristics can be used to predict bidirectional responses of productivity, or how other correlated variables may interact with climate to introduce spatial heterogeneity of carbon flux responses at the landscape scale. Our findings provide new mechanistic insight into the response of soil respiration within complex landscapes, and they provide a framework for representing the spatial variability of belowground processes over complex terrain.

\section{Conclusions}

In this article, we analyzed the variability of seasonal soil respiration in response to changes in precipitation inputs, using measurements taken from 62 soil respiration locations distributed across a moderately complex watershed of the northern Rocky Mountains. We treated landscape position as a continuously distributed variable and examined the spatial manifestation of the parabolic relationship between soil respiration and soil moisture. Our results showed that landscape-scale soil respiration exhibits bidirectional behavior in response to inter-annual water availability. We demonstrate that locations with high drainage areas (i.e., lowlands and wet areas of the forest) had higher cumulative soil respiration in dry years, whereas locations with low drainage areas (i.e., uplands and dry areas of the forest) had higher cumulative soil respiration in wet years. Our results indicate that for $80.9 \%$ of the forest soil respiration is likely to increase during wet years, whereas for $19.1 \%$ of the forest soil respiration is likely to decrease under the same hydrologic conditions. These results reveal an important emergent, bidirectional behavior of complex landscapes that is generated from the interaction of three relatively simple elements (parabolic soil biophysics, the relative distribution of landscape positions, and inter-annual climate variability), and which may mediate the responses of belowground $\mathrm{C}$ processes to changing climate.

Our findings have implications for quantifying $\mathrm{CO}_{2}$ losses from soils in response to climate variability and highlight the potential for overestimation of soil respiration rates in mountainous areas of models that omit the horizontal redistribution of water imposed by topography. Long-term measurements in the mountain regions of the western USA as well as in other biomes show that soil respiration is increasing in response to climate warming (Monson et al., 2006; Bond-Lamberty \& Thomson, 2010). We demonstrated that the morphology of mountain landscapes mediates the sensitivity of this flux to climate change. Inter-annual variability in hydrologic regimes affects soil water content and soil biogeochemical processes differentially across the landscape. This bidirectional response may counteract the effects of rising temperatures and demonstrates that prognostic models must account for topographic effects on biophysical processes to accurately quantify soil respiration rates in areas of complex terrain. 
Acknowledgments - This work was supported by the US National Science Foundation (Grants EAR-0404130, DEB-0807272). Additional support was provided by the 2007 AGU Horton Research Grant. Airborne Lidar was provided by the NSF-supported National Center for Airborne Laser Mapping (NCALM) at the University of California, Berkeley. We thank Robert E. Keane and Elaine Sutherland of the USDA Forest Service Rocky Mountain Research Station, Tenderfoot Creek Experimental Forest for site access and logistical support. V. Pacific, R. McNamara, and K. Conde provided field assistance. We thank Dr. Ankur Desai (University of Wisconsin), an anonymous reviewer, and the associate editor for valuable comments that improved a previous version of this manuscript, and Dr. Joseph Skopp (University of Nebraska) for insightful discussion on the soil moisture-soil respiration relationship.

\section{References}

Anderson-Teixeira KJ, Delong JP, Fox AM, Brese DA, Litvak ME (2011) Differential responses of production and respiration to temperature and moisture drive the carbon balance across a climatic gradient in New Mexico. Global Change Biology, 17, 410-424.

Barnett TP, Adam JC, Lettenmaier DP (2005) Potential impacts of a warming climate on water availability in snow-dominated regions. Nature, 438, 303-309.

Beven KJ, Gilman K, Newson M (1979) Flow and flow routing in upland channel networks. Hydrological Sciences Bulletin, 24, 303-325. Bond-Lamberty B, Thomson A (2010) Temperatureassociated increases in the global soil respiration record. $\mathrm{Na}$ ture, 464, 579-U132.

Chatterjee S, Hadi AS (1986) Influential observations, high leverage points, and outliers in linear regression. Statistical Science, 1, 379-416.

Christensen TR, Johansson T, Akerman HJ et al. (2004) Thawing sub-artic permafrost: effects on vegetation and methane emissions. Geophysical Research Letters, 31, L04501, doi: 10.1029/2003/GL018680.

Conner WH, Song B, Williams TM, Vernon JT (2011) Long-term tree productivity of a South Carolina coastal plain forest across a hydrology gradient. Journal of Plant Ecology, 4, 67-76. doi: 10.1093/jpe/rtq036.

Desai AR, Moore DJP, Ahue W et al. (in press) Seasonal pattern of regional carbon balance in the central rocky mountains from surface and airborne measurements. Journal of Geophysical Research, doi: 10.1029/2011JG001655.

Greaves JR, Carter EG (1920) Influence of moisture on the bacterial activities in the soil. Soil Science, 10, 361-387.

Huxman TE, Cable JM, Ignace DD, Eilts JA, English NB, Weltzin J, Williams DG (2004) Response of net ecosystem gas exchange to a simulated precipitation pulse in a semi-arid grassland: the role of native versus non-native grasses and soil texture. Oecologia, 141, 295-305.

IPCC (2007) Climate Change 2007: Impacts, Adaptation and Vulnerability. Contribution of Working Group Ii to the Fourth Assessment Report of the Intergovernmental Panel on Climate Change. IPCC, Cambridge, UK.

Jencso KG, McGlynn BL, Gooseff MN, Wondzell SM, Bencala KE, Marshall LA (2009) Hydrologic connectivity between land- scapes and streams: transferring reach and plot scale understanding to the catchment scale. Water Resources Research, 45, W04428, doi: 10.1029/2008WR007225.

Jenny H (1941) Factors of Soil Formation. Dover Publications, Inc, New York.

Kindler R, Siemens J, Kaiser K et al. (2011) Dissolved carbon leaching from soil is a crucial component of the net ecosystem exchange balance. Global Change Biology, 17, 1167-1185.

Law BE, Falge E, Gu L et al. (2002) Environmental controls over carbon dioxide and water vapor exchange of terrestrial vegetation. Agricultural and Forest Meteorology, 113, 97-120.

Linn DM, Doran JW (1984) Effect of water-filled pore-space on carbon-dioxide and nitrous-oxide production in tilled and nontilled soils. Soil Science Society of America Journal, 48, 1267-1272.

Liu XZ, Wan SQ, Su B, Hui DF, Luo YQ (2002) Response of soil $\mathrm{CO} 2$ efflux to water manipulation in a tallgrass prairie ecosystem. Plant and Soil, 240, 213-223.

Lohse KA, Brooks PD, McIntosh JC, Meixner T, Huxman TE (2009) Interactions between biogeochemistry and hydrologic systems. Annual Review of Environment and Resources, 34, 65-96.

Luyssaert S, Inglima I, Jung M et al. (2007) CO2 balance of boreal, temperate, and tropical forests derived from a global database. Global Change Biology, 13, 2509- 2537.

McGlynn BL, Seibert J (2003) Distributed assessment of contributing area and riparian buffering along stream networks. Water Resources Research, 39, 1082, doi: 10.1029/ 2002WR001525.

Mielnick PC, Dugas WA (2000) Soil CO2 flux in a tallgrass prairie. Soil Biology \& Biochemistry, 32, 221-228.

Monson RK, Lipson DL, Burns SP, Turnipseed AA, Delany AC, Williams MW, Schmidt SK (2006) Winter forest soil respiration controlled by climate and microbial community composition. Nature, 439, 711-714.

Montagnani L, Manca G, Canepa E et al. (2009) A new mass conservation approach to the study of $\mathrm{CO} 2$ advection in an Alpine forest. Journal of Geophysical Research- Atmospheres, 114, D07306, doi: 10.1029/2008JD010650.

Mote PW, Hamlet AF, Clark MP, Lettenmaier DP (2005) Declining mountain snowpack in western North America. Bulletin of the American Meteorological Society, 86, 39-49.

Pacific VJ, McGlynn BL, Riveros-Iregui DA, Welsch DL, Epstein HE (2008) Variability in soil respiration across riparian-hillslope transitions. Biogeochemistry, 91, 51-70, doi: 10.1007/ s10533-008-9258-8.

Pacific VJ, McGlynn BL, Riveros-Iregui DA, Epstein HE, Welsch DL (2009) Differential soil respiration responses to changing hydrologic regimes. Water Resources Research, 45, W07201, doi: 10.1029/2009WR007721.

Pacific VJ, McGlynn BL, Riveros-Iregui DA, Welsch DL, Epstein HE (2011) Landscape structure, groundwater dynamics, and soil water content influence soil respiration across riparian-hillslope transitions, Tenderfoot Creek Experimental Forest, Montana. Hydrological Processes, 25, 811-827, doi: 10.1002/ hyp.7870.

Piao SL, Friedlingstein P, Ciais P, Viovy N, Demarty J (2007) Growing season extension and its impact on terrestrial carbon cycle in the northern hemisphere over the past 2 decades. Global Biogeochemical Cycles, 21, Gb3018. 
Riveros-Iregui DA, McGlynn BL (2009) Landscape structure control on soil $\mathrm{CO} 2$ efflux variability in complex terrain: scaling from point observations to watershed scale fluxes. Journal of Geophysical Research, 114, G02010, doi: 10.1029/2008JG000885.

Riveros-Iregui DA, McGlynn BL, Epstein HE, Welsch DL (2008) Interpretation and evaluation of combined measurement techniques for soil $\mathrm{CO} 2$ efflux: discrete surface chambers and continuous soil CO2 concentration probes. Journal of Geophysical Research, 113, G04027, doi: 10.1029/2008JG000811.

Rodriguez-Iturbe I, Entekhabi D, Lee JS, Bras RL (1991) Nonlinear dynamics of soil moisture at climate scales .2. Chaotic Analysis. Water Resources Research, 27, 1907- 1915.

Schuur EAG, Vogel JG, Crummer KG, Lee H, Sickman JO, Osterkamp TE (2009) The effect of permafrost thaw on old carbon release and net carbon exchange from Tundra. Nature, 459, 556-559.

Seibert J, McGlynn BL (2007) A new triangular multiple flow direction algorithm for computing upslope areas from gridded digital elevation models. Water Resources Research, 43, W04501, doi: 10.1029/2006WR005128.

Sivapalan M, Wood EF (1986) Spatial heterogeneity and scale in the infiltration response of catchments. In: Scale Problems in Hydrology (eds. Gupta VK, Rodriguez-Iturbe I, Wood EF), pp. 81-106. D. Reidel Publishing Company, Dordrecht, Holland.

Skopp J, Jawson MD, Doran JW (1990) Steady-state aerobic microbial activity as a function of soil-water content. Soil Science Society of America Journal, 54, 1619-1625.
Sponseller RA, Fisher SG (2008) The influence of drainage networks on patterns of soil respiration in a desert catchment. Ecology, 89, 1089-1100.

Stoy PC, Katul GG, Siqueira MBS et al. (2008) Role of vegetation in determining carbon sequestration along ecological succession in the southeastern United States. Global Change Biology, 14, 1409-1427.

Trauth MH (2007) Matlab Recipes for Earth Sciences (2nd edn.). Springer, New York.

Walter KM, Zimov SA, Chanton JP, Verbyla D, Chapin FS (2006) Methan bubbling from Siberian thaw lakes as a positive feedback to climate warming. Nature, 443, 71-75, doi: 10.1038/ nature05040.

Western AW, Grayson RB, Bloschl G (2002) Scaling of soil moisture: a hydrologic perspective. Annual Review of Earth and Planetary Sciences, 30, 149-180.

Wilson KB, Baldocchi DD (2001) Comparing independent estimates of carbon dioxide exchange over 5 years at a deciduous forest in the southeastern United States. Journal of Geophysical Research-Atmospheres, 106, 34167-34178.

Xu LK, Baldocchi DD, Tang JW (2004) How soil moisture, rain pulses, and growth alter the response of ecosystem respiration to temperature. Global Biogeochemical Cycles, 18, Gb4002.

Yuan WP, Luo YQ, Richardson AD et al. (2009) Latitudinal patterns of magnitude and interannual variability in net ecosystem exchange regulated by biological and environmental variables. Global Change Biology, 15, 2905-2920. 